\title{
Nanoparticles for Cardiovascular Imaging and Therapeutic Delivery, Part 2: Radiolabeled Probes
}

\author{
John C. Stendahl ${ }^{1,2}$ and Albert J. Sinusas ${ }^{1-3}$ \\ ${ }^{I}$ Department of Internal Medicine, Section of Cardiovascular Medicine, Yale University School of Medicine, New Haven, \\ Connecticut; ${ }^{2}$ Yale Translational Research Imaging Center, Yale University School of Medicine, New Haven, Connecticut; \\ and ${ }^{3}$ Department of Diagnostic Radiology, Yale University School of Medicine, New Haven, Connecticut
}

\begin{abstract}
Nanoparticulate imaging agents and therapeutics have proven to be valuable tools in preclinical cardiovascular disease research. Because of their distinct properties and significant functional versatility, nanoparticulate imaging agents afford certain capabilities that are typically not provided by traditional small molecule agents. This review is the second in a two-part series covering nanoparticulate imaging agents and theranostics. It highlights current examples of radiolabeled nanoparticulate probes in preclinical cardiovascular research and demonstrates their utility in applications such as blood pool imaging and molecular imaging of ischemia, angiogenesis, atherosclerosis, and inflammation. These agents provide valuable insight into the molecular and cellular mechanisms of cardiovascular disease and illustrate both the limitations and the significant potential of nanoparticles in diagnostic and therapeutic applications. Further technologic development to improve performance, address safety concerns, and fulfil regulatory obligations is required for clinical translation of these emergent technologies.
\end{abstract}

Key Words: nanoparticles; cardiovascular disease; PET; SPECT; molecular imaging

J Nucl Med 2015; 56:1637-1641

DOI: 10.2967/jnumed.115.164145

Nanoparticles have garnered significant interest as agents for cardiovascular imaging and therapeutic delivery. Nanoparticulate imaging agents typically demonstrate pharmacokinetic and biodistribution behavior different from that of small molecules and provide flexible platforms for integration of multiple functional entities, including targeting ligands, therapeutics, and/or multiple types of contrast materials. Importantly, nanoparticulate imaging agents are also capable of amplifying signals by delivering large volumes of contrast materials in concentrated packages. Despite these intriguing attributes, nanoparticulate imaging agents have thus far

Received Jul. 20, 2015; revision accepted Jul. 23, 2015.

For correspondence or reprints contact: Albert J. Sinusas, Yale University

School of Medicine, 333 Cedar St., P.O. Box 208017, New Haven, CT 06520.

E-mail: albert.sinusas@yale.edu

Published online Aug. 20, 2015.

COPYRIGHT (C) 2015 by the Society of Nuclear Medicine and Molecular Imaging, Inc. attained only limited clinical use and require additional development to overcome various functional limitations and safety concerns.

This review is the second in a two-part series covering nanoparticulate imaging agents and theranostics. It describes current examples of radiolabeled nanoparticulate probes for PET and SPECT and highlights their utility in preclinical applications such as blood pool imaging and molecular imaging of ischemia, angiogenesis, atherosclerosis, and inflammation (Table 1). These agents provide valuable insight into the molecular and cellular mechanisms of cardiovascular disease and illustrate both the limitations and the significant potential of nanoparticles in diagnostic and therapeutic applications. Nanoparticle-based cardiovascular imaging via other modalities such as CT and MR has previously been reviewed in more detail elsewhere $(1-4)$.

\section{ISCHEMIA}

Radiolabeled nanoparticles have been used to detect and characterize ischemic and infarcted tissue and to deliver relevant therapeutics. Although perfusion is reduced under conditions of ischemia and infarction, the associated vascular injury results in higher permeability than healthy tissue and allows for passive nanoparticle targeting via the enhanced permeability and retention effect. Lukyanov et al. demonstrated this passively targeted delivery strategy by showing increased uptake of ${ }^{111}$ In-labeled polymeric micelles in infarcted rabbit myocardium (5). In a separate study, ${ }^{99 \mathrm{~m} T c}$ labeling was used to monitor retention of chitosan nanoparticles delivered by direct injection into ischemic myocardium (6). Similar, unlabeled, chitosan particles containing vascular endothelial growth factor were shown to increase perfusion to the ischemic tissue $1 \mathrm{wk}$ after administration. Passively targeted delivery of therapeutics via nanoparticles has also been demonstrated in the ischemic brain, where ${ }^{18} \mathrm{~F}$-labeled liposomes containing hemoglobin were shown to preferentially deposit in the ischemic zone of a middle cerebral artery thrombosis model despite very low perfusion levels (7).

\section{ANGIOGENESIS}

Radiolabeled nanoparticles have also been used for targeted molecular detection and characterization of new 
TABLE 1

Summary of Select Nanoparticle Applications in Nuclear Cardiovascular Imaging

\begin{tabular}{|c|c|c|c|c|c|c|}
\hline Imaging target & Particle type & Mean diameter & $\begin{array}{l}\text { Targeting } \\
\text { strategy }\end{array}$ & Labeling agent & Imaging modality & Reference \\
\hline \multirow[t]{2}{*}{$\begin{array}{l}\text { Ischemic } \\
\text { myocardium }\end{array}$} & $\begin{array}{l}\text { Polymeric } \\
\text { micelles }\end{array}$ & $7-20 \mathrm{~nm}$ & Passive & ${ }^{111}$ In & $\gamma$-camera & 5 \\
\hline & $\begin{array}{l}\text { Chitosan } \\
\text { nanoparticles }\end{array}$ & $100-150 \mathrm{~nm}$ & Passive & 99mTc & ARG & 6 \\
\hline Ischemic brain & Liposomes & $210 \mathrm{~nm}$ & Passive & ${ }^{18} \mathrm{~F}$ & PET & 7 \\
\hline \multirow[t]{6}{*}{ Angiogenesis } & Dendrimers & $\begin{array}{l}12 \mathrm{~nm} \\
\text { (prelabeling) }\end{array}$ & $\begin{array}{l}\text { RGD peptide } \\
\text { (binds } \alpha_{v} \beta_{3} \text { ) }\end{array}$ & ${ }^{76} \mathrm{Br}$ & PET/CT & 9 \\
\hline & $\begin{array}{l}\text { Comblike } \\
\text { polymeric } \\
\text { nanoparticles }\end{array}$ & $22 \mathrm{~nm}$ & $\begin{array}{l}\text { C-type atrial } \\
\text { natriuretic } \\
\text { factor }\end{array}$ & ${ }^{64} \mathrm{Cu}$ & PET/CT & 14 \\
\hline & $\begin{array}{l}\text { Gold } \\
\text { nanoparticles }\end{array}$ & $22 \mathrm{~nm}$ & $\begin{array}{l}\text { RGD peptide } \\
\text { (binds } \alpha_{v} \beta_{3} \text { ) }\end{array}$ & 99mTc, gold & SPECT/CT & 10 \\
\hline & $\begin{array}{l}\text { Perfluorocarbon } \\
\text { emulsion }\end{array}$ & $270 \mathrm{~nm}$ & $\begin{array}{l}\text { Nonpeptide } \alpha_{v} \beta_{3} \\
\text { antagonist }\end{array}$ & $\begin{array}{l}\text { 99mTc, } \mathrm{Gd}^{3+} \text {, } \\
\text { fluorophores }\end{array}$ & SPECT/CT/MR & 11 \\
\hline & $\begin{array}{l}\text { Single-walled } \\
\text { carbon } \\
\text { nanotubes }\end{array}$ & $1-5 \times 100-300 \mathrm{~nm}$ & $\begin{array}{l}\text { RGD peptide } \\
\text { (binds } \alpha_{v} \beta_{3} \text { ) }\end{array}$ & $\begin{array}{c}{ }^{64} \mathrm{Cu} \text {, carbon } \\
\text { nanotubes }\end{array}$ & $\begin{array}{l}\text { PET, Raman } \\
\text { spectroscopy } \\
\text { (ex vivo) }\end{array}$ & 12 \\
\hline & $\begin{array}{l}\text { Polymer-coated } \\
\text { UCNPs } \\
\left(\mathrm{NaGdF}_{4}:\right. \\
\left.\mathrm{Yb}^{3+} / \mathrm{Er}^{3+}\right)\end{array}$ & $32 \mathrm{~nm}$ & $\begin{array}{l}\text { RGD peptide } \\
\text { (binds } \alpha_{\mathrm{v}} \beta_{3} \text { ) }\end{array}$ & 124I, UCNP & $\begin{array}{l}\text { PET/MR, } \\
\text { upconversion } \\
\text { luminescence } \\
\text { (ex vivo) }\end{array}$ & 13 \\
\hline \multirow[t]{3}{*}{ Blood pool } & Dendrimers & $12 \mathrm{~nm}$ & Passive & 99mTc, TIBA & SPECT/CT & 15 \\
\hline & $\begin{array}{l}\text { Cross-linked } \\
\text { dextran shells/ } \\
\text { iron oxide } \\
\text { cores }\end{array}$ & $\begin{array}{c}20 \mathrm{~nm} \text { (base } \\
\text { particle) }\end{array}$ & Passive & $\begin{array}{l}{ }^{18} \mathrm{~F} \text {, iron oxide, } \\
\text { fluorophores }\end{array}$ & $\begin{array}{l}\mathrm{PET} / \mathrm{CT} / \mathrm{MR} \text {, } \\
\text { fluorescence } \\
\text { (ex vivo) }\end{array}$ & 16 \\
\hline & $\begin{array}{c}\text { Core-shell star } \\
\text { copolymers }\end{array}$ & $25-70 \mathrm{~nm}$ & Passive & ${ }^{64} \mathrm{Cu}$ & PET/CT & 17 \\
\hline \multirow[t]{2}{*}{ Atheromata } & LDL & $20 \mathrm{~nm}$ & $\begin{array}{l}\text { Apolipoproteins } \\
\text { (bind LDL } \\
\text { receptor) }\end{array}$ & 123 & $\gamma$-camera & 19 \\
\hline & $\begin{array}{l}\text { Reconstituted } \\
\text { HDL particles } \\
\text { with QD/iron } \\
\text { oxide cores }\end{array}$ & $8-12 \mathrm{~nm}$ & $\begin{array}{l}\text { Apolipoproteins } \\
\text { (bind HDL } \\
\text { receptor) }\end{array}$ & $\begin{array}{l}{ }^{59} \mathrm{Fe}, \mathrm{CdSE} / \mathrm{CdS} / \\
\text { ZnS QDs, iron } \\
\text { oxide }\end{array}$ & $\begin{array}{l}\text { MR, fluorescence, } \\
\gamma \text {-counter } \\
\text { (ex vivo) }\end{array}$ & 22 \\
\hline \multirow[t]{3}{*}{$\begin{array}{l}\text { Atheromata } \\
\text { (intraplaque } \\
\text { inflammation) }\end{array}$} & Dendrimers & NA & $\begin{array}{l}\text { LyP-1 peptide } \\
\text { (binds } \\
\text { macrophages) }\end{array}$ & $\begin{array}{l}{ }^{64} \mathrm{Cu}, \\
\quad \text { fluorophores }\end{array}$ & $\begin{array}{l}\text { PET/CT, } \\
\text { fluorescence } \\
\text { (ex vivo) }\end{array}$ & 24 \\
\hline & $\begin{array}{l}\text { Comblike } \\
\text { polymer } \\
\text { nanoparticles }\end{array}$ & $15 \mathrm{~nm}$ & $\begin{array}{l}\text { DAPTA (modified } \\
\text { peptide, binds } \\
\text { chemokine } \\
\text { receptor-5) }\end{array}$ & ${ }^{64} \mathrm{Cu}$ & $\mathrm{PET} / \mathrm{CT}$ & 25 \\
\hline & $\begin{array}{l}\text { Dextran } \\
\quad \text { nanoparticles }\end{array}$ & $13 \mathrm{~nm}$ & Passive & $\begin{array}{l}{ }^{89} \mathrm{Zr} \text {, } \\
\text { fluorophores }\end{array}$ & $\begin{array}{l}\text { PET/MR, ARG, } \\
\text { fluorescence } \\
\text { (ex vivo) }\end{array}$ & 26 \\
\hline $\begin{array}{l}\text { Cardiac } \\
\text { allografts } \\
\text { (graft } \\
\text { inflammation) }\end{array}$ & $\begin{array}{l}\text { Cross-linked } \\
\text { dextran shells/ } \\
\text { iron oxide } \\
\text { cores }\end{array}$ & $20 \mathrm{~nm}$ & Passive & $\begin{array}{l}{ }^{64} \mathrm{Cu} \text {, iron oxide, } \\
\text { fluorophores }\end{array}$ & $\begin{array}{l}\text { PET/CT, ARG, } \\
\text { fluorescence } \\
\text { (ex vivo) }\end{array}$ & 29 \\
\hline $\begin{array}{l}\text { Aortic } \\
\text { aneurysms } \\
\text { (mural } \\
\text { inflammation) }\end{array}$ & $\begin{array}{l}\text { Cross-linked } \\
\text { dextran shells/ } \\
\text { iron oxide } \\
\text { cores }\end{array}$ & $\begin{array}{c}20 \mathrm{~nm} \text { (base } \\
\text { particle) }\end{array}$ & Passive & $\begin{array}{l}{ }^{18} \mathrm{~F} \text {, iron oxide, } \\
\text { fluorophores }\end{array}$ & $\begin{array}{l}\text { PET/CT, ARG, } \\
\text { fluorescence } \\
\text { (ex vivo) }\end{array}$ & 30 \\
\hline
\end{tabular}

UCNP = upconversion nanophosphor; TIBA = 2,3,5-triiodobenzoic acid; LDL = low-density lipoprotein; HDL = high-density lipoprotein; $\mathrm{QD}=$ quantum dot; NA = not available; $\mathrm{ARG}=$ autoradiography. 


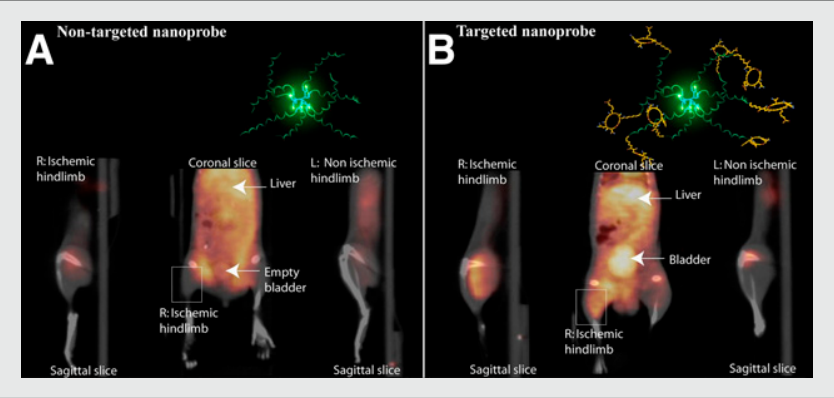

FIGURE 1. PET/CT images of angiogenesis in murine model of hind limb ischemia. Animals were injected with ${ }^{125}$ |-labeled dendrimers $24 \mathrm{~h}$ before imaging. The PET signal is significantly greater in ischemic limb muscle imaged with $\alpha_{v} \beta_{3}$-targeted dendrimers $(B)$ than in muscle imaged with nontargeted dendrimers (A). (Reprinted with permission of (9).)

microvessels formed by angiogenesis. Potential clinical applications of angiogenesis imaging within the cardiovascular system include characterization of ischemia-induced angiogenesis and detection of intraplaque angiogenesis that predisposes to plaque rupture. The most established molecular target for angiogenesis is the $\alpha_{\nu} \beta_{3}$ integrin, a heterodimeric transmembrane protein that is expressed on many cell types but differentially upregulated on proliferating endothelial cells (8). Nanoparticles targeted toward $\alpha_{\nu} \beta_{3}$ integrins are well suited for angiogenesis imaging because they can limit signals from nonangiogenic $\alpha_{\nu} \beta_{3}$ binding through multivalent ligand presentation and size-based vascular compartment confinement. Almutairi et al. successfully used ${ }^{76} \mathrm{Br}$-labeled mul-

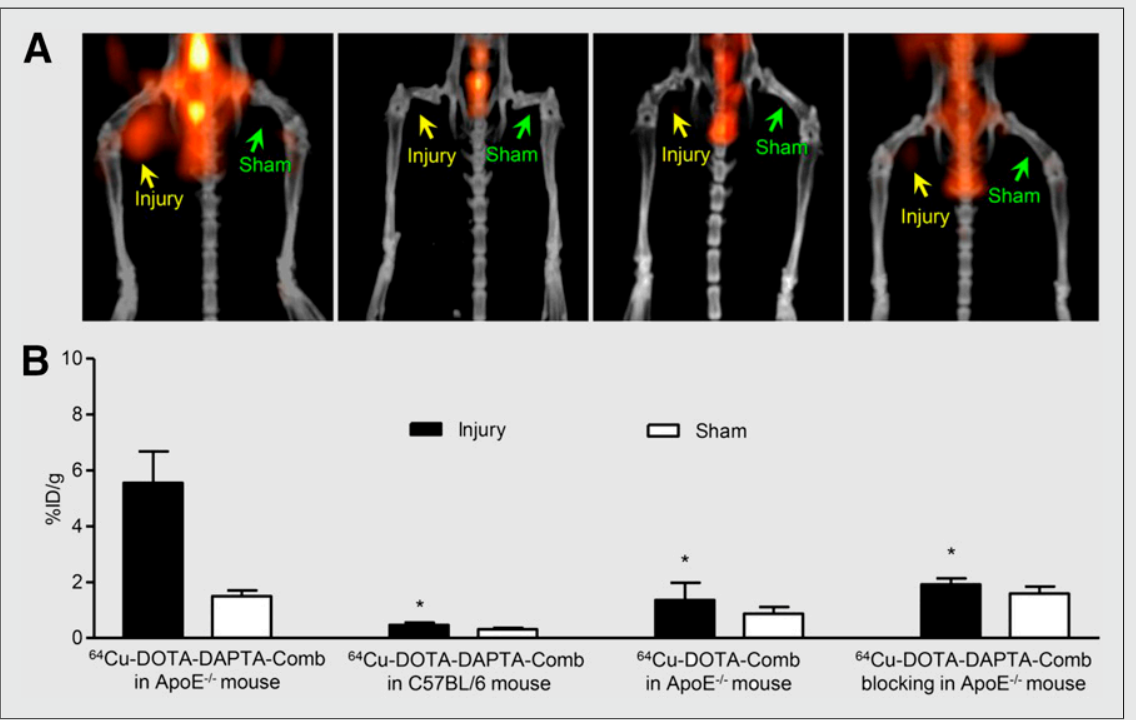

FIGURE 2. (A) 24-h maximum-intensity PET/CT projection images showing uptake of ${ }^{64} \mathrm{Cu}$-labeled comblike polymer nanoparticles in a murine model of wire-injuryinduced atherosclerosis 2 wK after injury. Nanoparticles displaying D-Ala ${ }_{1}$-peptides (DAPTA), which bind chemokine receptor 5 in inflamed atheromas, exhibited substantially greater uptake in atherosclerosis-susceptible $\mathrm{ApoE}^{-/-}$mice than in non-ApoE ${ }^{-/-}$, non-DAPTA, and DAPTA-blocked controls. (B) Quantification of nanoparticle uptake in corresponding images. Data are mean \pm SEM $\left({ }^{\star} P<0.001\right)$. Collectively, these images demonstrate the potential utility of chemokine receptor 5-targeted nanoparticles in the imaging of atherosclerotic lesions (25). tivalent dendrimers with $\alpha_{\nu} \beta_{3}$-targeted peptides for PET/ CT detection of angiogenesis in a murine model of hind limb ischemia (Fig. 1) (9). The power of presenting multiple $\alpha_{\nu} \beta_{3}$-binding epitopes on a single dendrimer surface is onstrated by the fact that the multivalent dendrimers a 50 -fold enhancement in $\alpha_{\nu} \beta_{3}$ binding affinity , and lanthanide upconversion nanophosphors (13). Another molecular target for angiogenesis imaging is natripeptide receptor $\mathrm{C}$, which was targeted with a novel polymeric nanoparticle functionalized with $\mathrm{C}$-type imaging (14). This natriuretic peptide receptor C-targeted nas used to noninvasively detect angiogen-

\section{BLOOD POOL IMAGING}

Nanoparticles are also potentially useful as blood pool imaging agents because they can be designed for extended circulation with minimal extravasation into the surrounding tissue. Examples of nanoparticulate blood pool agents in nuclear imaging include multimodal dendrimers for SPECT/ (15), multimodal cross-linked dextran iron oxide agents for /CT and PET/MR (16), and core-shell star copolymers for PET (17). The long circulation times of these particles are primarily attributable to their intermediate sizes and surface functionalization with polyethylene glycol moieties. These and other nanoparticulate agents may be useful for detection and characterization of ischemic heart and peripheral vascular diseases, including those related to microvascular dysfunction.

Given their capacity for extended circulation times, nanoparticulate blood pool agents are also potentially useful for defining vascular and cardiac structures. For example, nanoparticulate CT blood pool agents could be used with cine CT imaging for evaluation of the endocardial and epicardial surfaces. The use of this technique in combination with myocardial radiotracers in hybrid SPECT/CT or PET/CT imaging could allow for absolute radiotracer quantification with incorporation of partial-volume corrections for regional differences in wall thickness. Long-circulating nanoparticulate agents are also especially useful in small-animal SPECT/CT and PET/CT blood pool imaging, where CT images may be acquired over periods of 


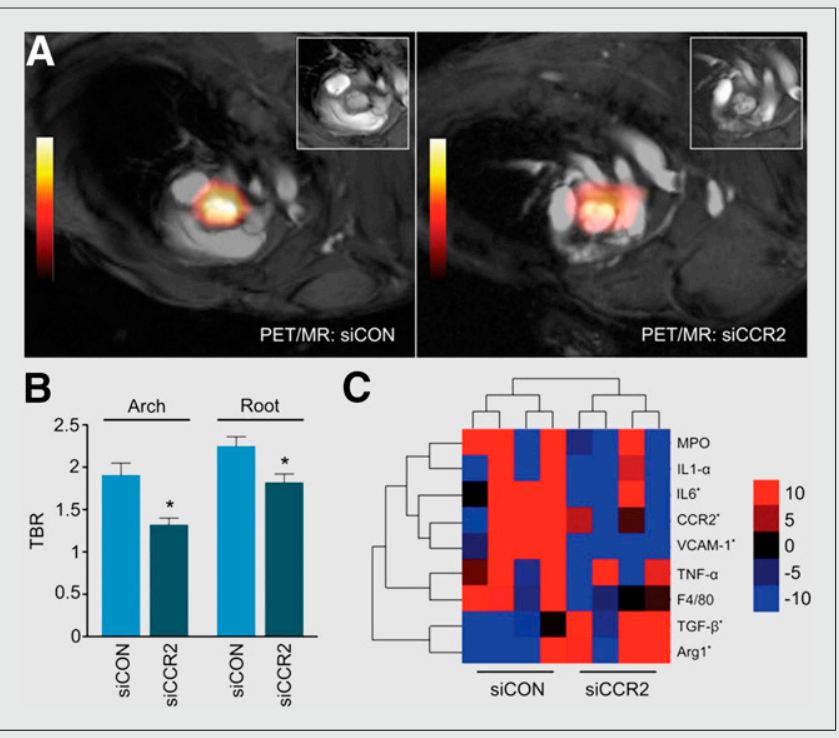

FIGURE 3. (A) Representative PET/MR images showing uptake of ${ }^{89} \mathrm{Zr}$-dextran nanoparticles passively targeted toward monocytes and macrophages in aortic plaques of apolipoprotein E-deficient mice. Before imaging, mice were treated with separate lipid nanoparticles containing either control small interfering RNA (siCON) or small interfering RNA to silence chemokine receptor-2 (siCCR2). (B) Mean target-to-background ratios (TBR) from PET images showing siCCR2 nanoparticlerelated suppression of PET signals due to attenuated monocyte recruitment ( $n=5$ per group; error bars represent SEM, ${ }^{*} P<$ 0.05). (C) Heat map of gene expression in aortic roots for siCON and siCCR2 subjects ( $n=4$ per group), where red indicates increased expression and blue indicates decreased expression. Arg1 = arginase 1; F4/80 = murine macrophage marker; IL = interleukin; MPO = myeloperoxidase; TGF = transforming growth factor; TNF = tumor necrosis factor; VCAM = vascular cell adhesion molecule. (Reprinted with permission of (26).)

several minutes without the substantial clearance that occurs with conventional small molecule CT contrast agents (15).

Nanoparticulate SPECT and CT contrast agents that remain in the vascular compartment for extended periods could also be used to evaluate the myocardial microcirculation, which is the primary determinant of intramyocardial blood volume. Conventional small molecule contrast agents tend to overestimate intramyocardial blood volume because of significant first-pass myocardial extraction (18). Quantitative analysis of myocardial blood flow could also be accomplished via kinetic modeling of purely intravascular nanoparticle CT contrast agents imaged via high-resolution dynamic cine CT (18).

\section{ATHEROSCLEROSIS}

Radiolabeled nanoparticles are well suited for detection and characterization of atherosclerotic lesions because their depth of tissue penetration typically does not exceed lesion thicknesses. Radiolabeled lipoprotein nanoparticles such as highand low-density lipoproteins have been used since the 1980s to monitor lipoprotein particle circulation and lipid uptake in atheromatous lesions (19-21). Endogenous high-density lipo- protein particles have dimensions on the order of 5-15 nm and are favorably suited for vascular imaging applications because of the ease with which they can be isolated and radiolabeled and their intrinsic uptake in atherosclerotic lesions. Since initial studies nearly $30 \mathrm{y}$ ago, numerous advances have been made, including the development of particles with synthetic or reconstituted lipoprotein shells that are designed for multimodal imaging and therapeutic delivery (22). Lipoprotein nanoparticles have also been used extensively in studies involving nonnuclear imaging modalities such as MR; a review of this literature is available elsewhere (23).

Radiolabeled nanoparticles have also played significant roles in recent efforts to characterize intraplaque inflammation, which can induce thinning of fibrous caps on lesions and make them vulnerable to rupture. Nanoparticles targeted toward inflammatory cells have proven to be effective agents for detecting intraplaque inflammation and may provide ideal substrates for delivering interventional payloads to stabilize plaques before they rupture and cause serious vascular events. Recent examples of nanoparticle-targeted intraplaque inflammatory cell imaging include ${ }^{64} \mathrm{Cu}$-labeled dendrimers targeted toward macrophages with LyP-1 peptides (PET/CT) $(24),{ }^{64} \mathrm{Cu}$-labeled synthetic polymer particles targeted toward chemokine receptor 5 on monocytes (PET/CT) (Fig. 2) (25), and ${ }^{89} \mathrm{Zr}$-labeled dextran nanoparticles passively targeted toward intraplaque monocytes and macrophages (PET/MR) (Fig. 3) (26). In this last case, separate lipid nanoparticles containing small interfering RNA to silence chemokine receptor 2, a receptor involved in recruitment of inflammatory monocytes (27), were also passively delivered to plaque monocytes and macrophages. Decreased uptake of ${ }^{89} \mathrm{Zr}$-labeled dextran nanoparticles after delivery of targeted small interfering RNA demonstrated the potential of this approach for vulnerable plaque detection and preemptive stabilization.

Of related interest, van der Valk et al. recently published results of a first-in-human trial of liposome-mediated delivery of the antiinflammatory drug prednisolone to atheromata (28). Although ex vivo analysis demonstrated successful liposomal delivery to plaque macrophages, no decreases in vessel permeability were detected with dynamic contrast-enhanced MR imaging and no localized antiinflammatory effects were detected with ${ }^{18}$ F-FDG PET/CT. Despite the lack of efficacy, this study importantly demonstrates the clinical feasibility of nanomedicinal delivery to atherosclerotic plaques and illustrates the potentially complementary roles of nanomedicine and advanced imaging in the clinical management of cardiovascular disease.

\section{ADDITIONAL CARDIOVASCULAR APPLICATIONS OF INFLAMMATORY CELL IMAGING}

Inflammatory cell imaging via radiolabeled nanoparticles has also been applied to other areas of diagnostic cardiovascular imaging research. Ueno et al. used PET/CT and passively targeted dextran-coated cross-linked iron oxide nanoparticles labeled with ${ }^{64} \mathrm{Cu}$ to quantify myeloid cell infiltration in murine cardiac allografts and predict graft rejection and survival (Fig. 4) (29). The same laboratory also 


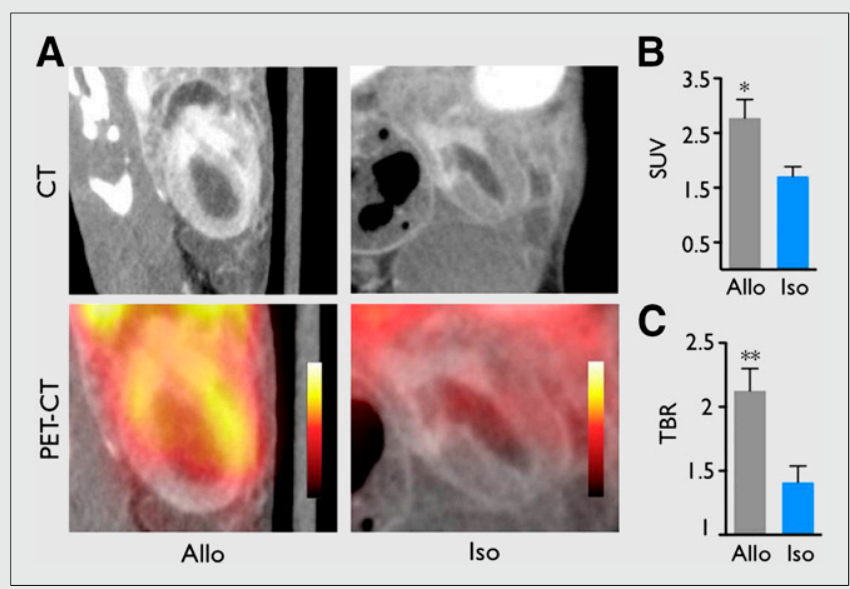

FIGURE 4. (A) PET/CT images comparing inflammation in murine cardiac allo- and isografts on day 7 after transplantation. Animals were injected with ${ }^{64} \mathrm{Cu}$-labeled dextran shell/iron oxide core nanoparticles $24 \mathrm{~h}$ before imaging. Passively targeted nanoparticles are effective reporters of graft inflammation because they are known to be taken up at high levels by myeloid cells but at negligible levels by other cardiac cells. (B and C) Quantification of PET images. Allografts exhibited significantly greater mean standardized uptake value (SUV) and mean target-to-background ratio (TBR) than isograft controls, demonstrating the potential utility of the dextran/iron oxide nanoparticles in assessment of graft rejection. Data are mean \pm SEM ( ${ }^{\star} P<0.05$. ${ }^{\star \star} P<0.01$ ). (Reprinted with permission of (29).)

used PET/CT imaging with passively targeted ${ }^{18} \mathrm{~F}$-labeled cross-linked iron oxide nanoparticles to quantify aortic aneurysm macrophages in a murine model of aortic aneurysm (30). They were able to demonstrate in this pilot study that the magnitude of the macrophage-targeted PET/CT signal had predictive value for dimensional stability of aneurysms.

\section{CONCLUSION}

The diverse array of nanoparticulate imaging agents and theranostics described above illustrates the current utility of nanoparticles in cardiovascular imaging and therapy. These agents provide valuable insight into the molecular and cellular mechanisms of cardiovascular disease and illustrate both the limitations and the significant potential of nanoparticles in diagnostic and therapeutic applications. Further technologic development to improve performance, address safety concerns, and fulfil regulatory obligations is required for clinical translation of these emergent technologies.

\section{DISCLOSURE}

Dr. Stendahl is supported by NIH T32 training grant HL098069. No other potential conflict of interest relevant to this article was reported.

\section{REFERENCES}

1. Strijkers GJ. Targeted nanoparticles for cardiovascular molecular imaging. Curr Radiol Rep. 2013;1:191-204.

2. Mulder WJM, Jaffer FA, Fayed ZA, Nahrendorf M. Imaging and nanomedicine in inflammatory atherosclerosis. Sci Transl Med. 2014;6:239sr1.
3. Chen HH, Josephson L, Sosnovik DE. Imaging of apoptosis in the heart with nanoparticle technology. Wiley Interdiscip Rev Nanomed Nanobiotechnol. 2011;3:86-99.

4. Chen W, Cormode DP, Fayad ZA, Mulder WJ. Nanoparticles as magnetic resonance imaging contrast agents for vascular and cardiac diseases. Wiley Interdiscip Rev Nanomed Nanobiotechnol. 2011;3:146-161.

5. Lukyanov AN, Hartner WC, Torchilin VP. Increased accumulation of PEG-PE micelles in the area of experimental myocardial infarction in rabbits. $J$ Control Release. 2004;94:187-193.

6. Hwang H, Kwon J, Oh P-S, et al. Peptide-loaded nanoparticles and radionuclide imaging for individualized treatment of myocardial ischemia. Radiology. 2014;273:160-167.

7. Urakami T, Kawaguchi AT, Akai S, et al. In vivo distribution of liposomeencapsulated hemoglobin determined by positron emission tomography. Artif Organs. 2009;33:164-168.

8. Brooks PC, Clark RAF, Cheresh DA. Requirement of vascular integrin $\alpha_{\nu} \beta_{3}$ for angiogenesis. Science. 1994;264:569-571.

9. Almutairi A, Rossin R, Shokeen M, et al. Biodegradable dendritic positronemitting nanoprobes for the noninvasive imaging of angiogenesis. Proc Natl Acad Sci USA. 2009;106:685-690.

10. Morales-Avila E, Ferro-Flores G, Ocampo-Garcia BE, et al. Multimeric system of ${ }^{99 \mathrm{~m}} \mathrm{Tc}$-labeled gold nanoparticles conjugated to $\mathrm{c}[\mathrm{RGDfK}(\mathrm{C})]$ for molecular imaging of tumor $\alpha_{\nu} \beta_{3}$ expression. Bioconjug Chem. 2011;22:913-922.

11. Lijowski M, Caruthers S, Hu G, et al. High-resolution SPECT-CT/MR molecular imaging of angiogenesis in the Vx2 model. Invest Radiol. 2009;44:15-22.

12. Liu Z, Cai W, He L, et al. In vivo biodistribution and highly efficient tumour targeting of carbon nanotubes in mice. Nat Nanotechnol. 2007;2:47-52.

13. Lee J, Lee TS, Ryu J, et al. RGD peptide-conjugated multimodal $\mathrm{NaGdF}_{4}: \mathrm{Yb}^{3+}$ / $\mathrm{Er}^{3+}$ nanophosphors for upconversion luminescence, MR, and PET imaging of tumor angiogenesis. J Nucl Med. 2013;54:96-103.

14. Liu Y, Pressly ED, Abendschein DR, et al. Targeting angiogenesis using a C-type atrial natriuretic factor-conjugated nanoprobe and PET. J Nucl Med. 2011;52: 1956-1963.

15. Criscione JM, Dobrucki LW, Zhuang ZW, et al. Development and application of a multimodal contrast agent for SPECT/CT hybrid imaging. Bioconjug Chem. 2011;22:1784-1792.

16. Devaraj NK, Keliher EJ, Thurber GM, Nahrendorf M, Weissleder R. ${ }^{18} \mathrm{~F}$ labeled nanoparticles for in vivo PET-CT Imaging. Bioconjug Chem. 2009;20:397-401.

17. Fukukawa K, Rossin R, Hagooly A, et al. Synthesis and characterization of coreshell star copolymers for in vivo PET imaging applications. Biomacromolecules. 2008;9:1329-1339.

18. Canty JM, Judd RM, Brody AS, Klocke FJ. First-pass entry of nonionic contrast agent into the myocardial extravascular space. Circulation. 1991;84:2071-2078.

19. Sinzinger H, Bergmann H, Kaliman J, Angelberger P. Imaging of human atheroselerotic lesions using ${ }^{123}$ I-low-density lipoprotein. Eur J Nucl Med. 1986; 12:291-292.

20. Shaish A, Keren G, Chouraqui P, Levkovitz H. Imaging of aortic atherosclerotic lesions by ${ }^{125} \mathrm{I}-\mathrm{LDL},{ }^{125} \mathrm{I}$-oxidized-LDL, ${ }^{125} \mathrm{I}$-HDL and ${ }^{125} \mathrm{I}$-BSA. Pathobiology. 2001;69:225-229.

21. Iuliano L, Signore A, Vallabajosula S, et al. Preparation and biodistribution of ${ }^{99} \mathrm{~m}$ technetium labelled oxidized LDL in man. Atherosclerosis. 1996;126:131-141.

22. Jung C, Kaul MG, Bruns OT, et al. Intraperitoneal injection improves the uptake of nanoparticle-labeled high-density lipoprotein to atherosclerotic plaques compared with intravenous injection: a multimodal imaging study in ApoE knockout mice. Circ Cardiovasc Imaging. 2014;7:303-311.

23. Fay F, Sanchez-Gaytan BL, Cormode DP, et al. Nanocrystal core lipoprotein biomimetics for imaging of lipoproteins and associated diseases. Curr Cardiovasc Imaging Rep. 2013;6:45-54.

24. Seo JW, Baek H, Mahakian LM, et al. ${ }^{64} \mathrm{Cu}$-labeled LyP-1-dendrimer for PETCT imaging of atherosclerotic plaque. Bioconjug Chem. 2014;25:231-239.

25. Luehmann HP, Pressly ED, Detering L, et al. PET/CT imaging of chemokine receptor CCR5 in vascular injury model using targeted nanoparticle. J Nucl Med. 2014;55:629-634.

26. Majmudar MD, Yoo J, Keliher EJ, et al. Polymeric nanoparticle PET/MR imaging allows macrophage detection in atherosclerotic plaques. Circ Res. 2013; 112:755-761.

27. Leuschner F, Dutta $P$, Gorbatov $R$, et al. Therapeutic siRNA silencing in inflammatory monocytes in mice. Nat Biotechnol. 2011;29:1005-1010.

28. van der Valk FM, van Wijk DF, Lobatto ME, et al. Prednisolone-containing liposomes accumulate in human atherosclerotic macrophages upon intravenous administration. Nanomedicine. 2015;11:1039-1046.

29. Ueno T, Dutta P, Keliher E, et al. Nanoparticle PET-CT detects rejection and immunomodulation in cardiac allografts. Circ Cardiovasc Imaging. 2013;6:568-573.

30. Nahrendorf M, Keliher E, Marinelli B, et al. Detection of macrophages in aortic aneurysms by nanoparticle positron emission tomography-computed tomography. Arterioscler Thromb Vasc Biol. 2011;31:750-757. 